Dr. B. Stenge Csaba*

\title{
Egy magyar repülős századjelvény és annak készítője
}

A Magyar Királyi Honvéd Légierő repülőszázadainál alkalmazott századjelvények témájával ugyan érintőlegesen foglalkozott már több publikáció is és egy külön könyvecske is jelent már meg ezekről, ${ }^{1}$ ennek ellenére a jelvényekkel kapcsolatban még sok kutatni, tisztázni, pontosítani és bemutatni való van.

Ágoston József apai ágon nagykanizsai magyar, míg anyai ágon osztrák családból származott. Plzenben született 1917. szeptember 19-én, mivel hivatásos honvéd tiszthelyettes édesapja ekkor alakulatával és családjával együtt a cseh városban tartózkodott (a nagykanizsai császári és királyi 48. gyalogezred pótzászlóalja ekkor Plzenben állomásozott). ${ }^{2}$ Egy lánytestvére volt. Ágoston József Nagykanizsán és Szentpéterúron nőtt fel, a nagykanizsai fémipari szakiskola pécsi fémipariba történő beolvasztása miatt ezt már Pécsett fejezte be 1935-ben, de ezt követően vissza-

1. ábra. Bombán lovagló ördög a szombathelyi 2/3. könnyübombázó repülöszázad századjelvényén

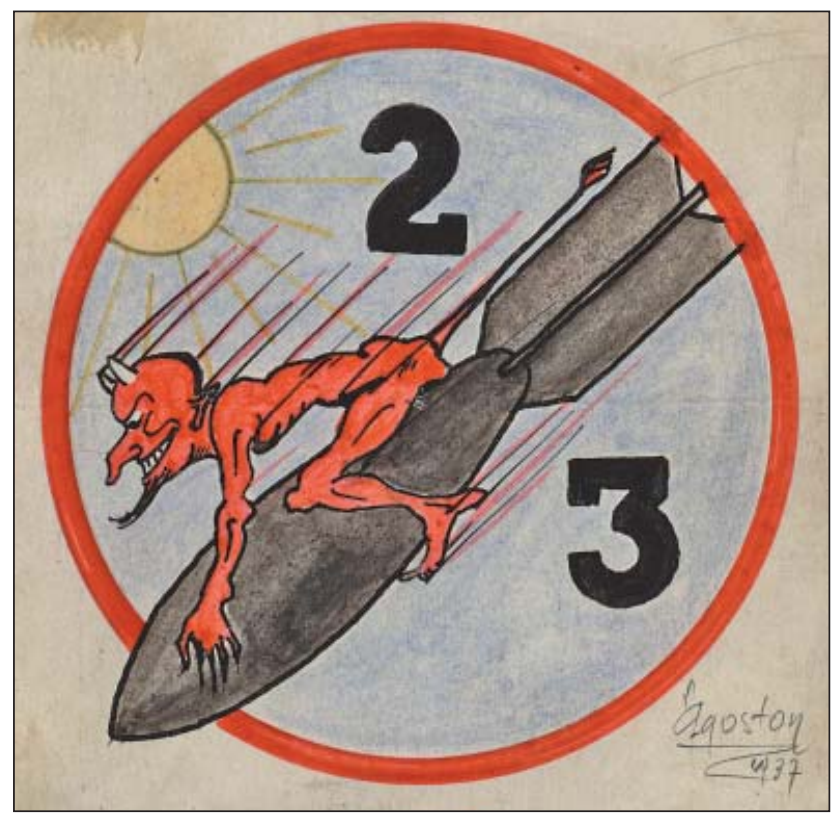

ÖSSZEFOGLALÁS: A magyar királyi honvéd légierők történetének érdekes színfoltja az adott időszak repülőszázadainál alkalmazott századjelvények története. Az alábbi tanulmány a magyar királyi honvéd légierők egy olyan egykori pilótáját és annak munkásságát mutatja be, aki az adott időszakban három századjelvényt is megtervezett és kivitelezett, ezek közül az egyik pedig ezidáig ismeretlen, publikálatlan volt.

KULCSSZAVAK: Magyar Királyi Honvéd Légierők, századjelvény, Ágoston József

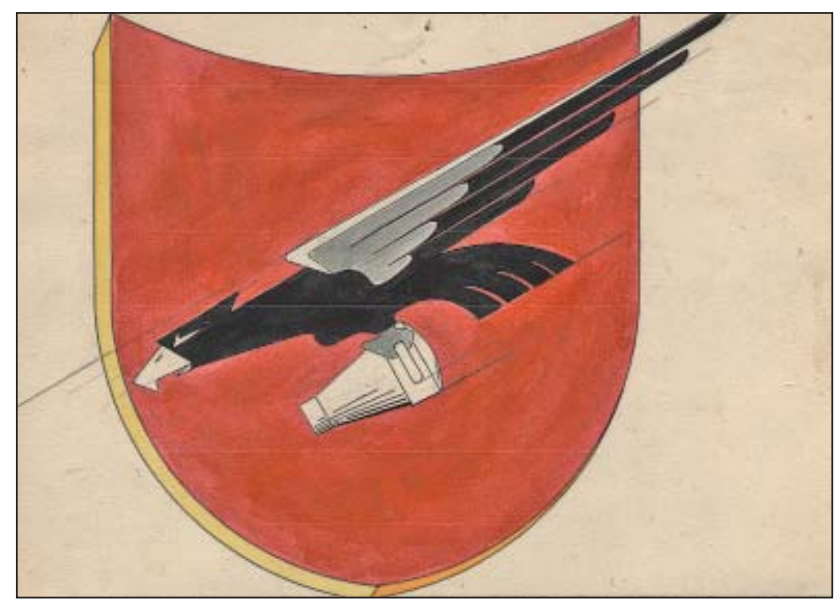

2. ábra. A Sólyom század tervezett jelvénye

tért szülővárosába, ahol esztergályos-segédként kezdett el dolgozni.

Ágoston József 1936. október 5-én korengedménnyel vonult be az ekkor még titkos Magyar Királyi Honvéd Légierőkhöz Szombathelyre, ahol repülőgép-vezetői kiképzésre jelentkezett, amelyet újonckiképzése után meg is kezdett. Szombathelyen nyerte el az I. és II. fokú pilótakiképzését is 1937-1938 folyamán (első fokon összesen 47 óra 15 perc repült ideje volt 277 kétkormányos és 55 egyedüli felszállás során, míg másodfokon 4 óra 35 perc repült ideje 36 kétkormányos és 18 egyedüli felszállásból). ${ }^{3}$

Jó kézügyességére már ekkor, itt felfigyeltek. Ennek köszönhetően 1937-ben Szombathelyen készítette el az első repülő századjelvényét, amely az itt állomásozó, Czapáry Zoltán százados vezette $2 / 3$. könnyűbombázó-század bombán lovagló „Vörös Ördög” jelvénye lett, amely századba Ágoston József is beosztást nyert. (Ő maga későbbi visszaemlékezésében nagyon önkritikusan „anatómiai szörnyszülöttnek" nevezte a megrajzolt és alkalmazott figurát). ${ }^{4}$ Szakaszvezetői előléptetése és a továbbszolgálóvá történő átvétele 1938. október 1-vel történt meg.

Ágoston József harmadfokú pilótaképzését a REGVI-nél 1939-ben nyerte el (10 óra 45 perc repült idővel, ebből 85 kétkormányos és 65 egyedüli felszállással), repülőgép-ve-

ABSTRACT: Markings applied in air squadrons represent an interesting coloured part of the history of the Royal Hungarian Air Forces. The subject of this study is the former pilot of the air forces and his activities, who also designed and produced three squadron markings; one of them was unknown and unpublished so far.

KEY WORDS: Royal Hungarian Air Forces, squadron marking, József Ágoston

\footnotetext{
* Orcid: 0000-0003-2129-8697, Tatabánya Megyei Jogú Város Levéltára, igazgató /Tatabánya City Archives, Director
} 


\section{K. frep.szarad jelvenge.}

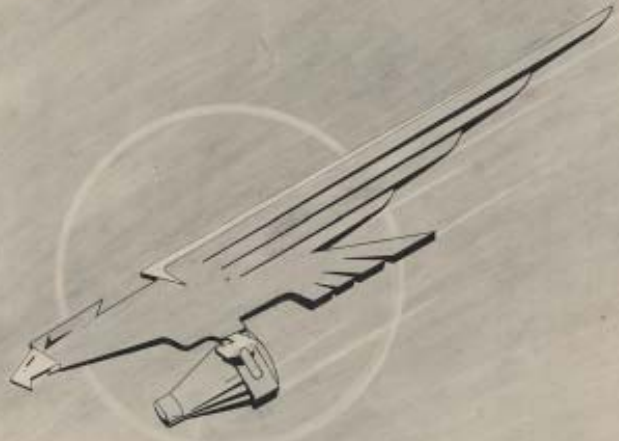

\section{3. ábra. A III. század hivatalos jelvénye}

zetői kinevezését 1939. április 20-ai dátummal kapta meg. Ezt követően 1939. június 12-től augusztus 26-ig felderítő harci iskolát végzett Ungváron. ${ }^{5}$ Felderítő harckiképzését befejezvén, 1939. október 1-vel került beosztásra egy éppen költöző, Csegezy József százados vezette közelfelderítő repülőszázadhoz. A pécsi IV. közelfelderítő század ekkor WM-21 Sólyom típusra történő átfegyverzés alatt állt, amely típus biztonságos üzemeltetéséhez a pécsi repülőtér túl rövidnek bizonyult. Ezért döntés született a század Szombathelyre történő áthelyezéséről, emiatt pedig
Vas megye székhelyén át is számozták III. közelfelderítő századdá (az átszámozásra azért került sor, mert költözésével a század a pécsi IV. hadtest alárendeltségéből a szombathelyi III. hadtest alárendeltségébe került). Ez volt a második század, amelynek jelvényét Ágoston József tervezte meg. A „Sólyom” század 1940-ben elkészített jelvénye egy karmaiban fényképező kézi kamerát tartó, zuhanó sólymot ábrázolt. A korábbi, élénk színekben pompázó századjelvény(ek) helyett ez azonban már egy kevésbé feltűnő jelvénytípus volt. Ágoston József visszaemlékezése szerint azért, mert „...1940-ben már a harci tapasztalatok alapján előírás szabályozta, hogy a harci gépekre felfestett jelvények ne legyenek nagyok és színesek, hogy légi harcban és alacsonytámadásnál ne szolgáljanak jó célpontul az ellenfélnek. Ilyen megkötések szem előtt tartásával született a fekete-fehér vonalakból kialakitott századjelvény." Ágoston József munkáinak ismertségét és elismertségét jelzi, hogy 1940 őszétől tréfás rajzai a korabeli repülő szaklapban, a Magyar Szárnyakban is megjelentek, a háború végéig nagyságrendileg harmincnál több (egyébként 1940. október 1-vel vették át őt a hivatásos állományba is). Az 1941-es év meghozta az igazi háborút százada számára is. A III. közelfelderítő-század előbb 1941 áprilisában részt vett a rövid, Jugoszlávia elleni hadjáratban - közvetlenül ezt követően, 1941. május 1-vel Ágoston József őrmesterré lépett elő -, majd eljött a valódi erőpróba is: a III. közelfelderítő század 1941. júliustól novemberig az I. gyorshadtest kíséretében részt vett a Szovjetunió elleni hadjáratban is.

A III. közelfelderítő századnál a Szovjetunió felett végrehajtott eredményes felderítő és közvetlen harctámogató bevetéseiért Ágoston József őrmester megkapta a Magyar

4. ábra. Készül a századjelvény: festékszórás a WM-21A Sólyom közelfelderítő repülőgép törzsére

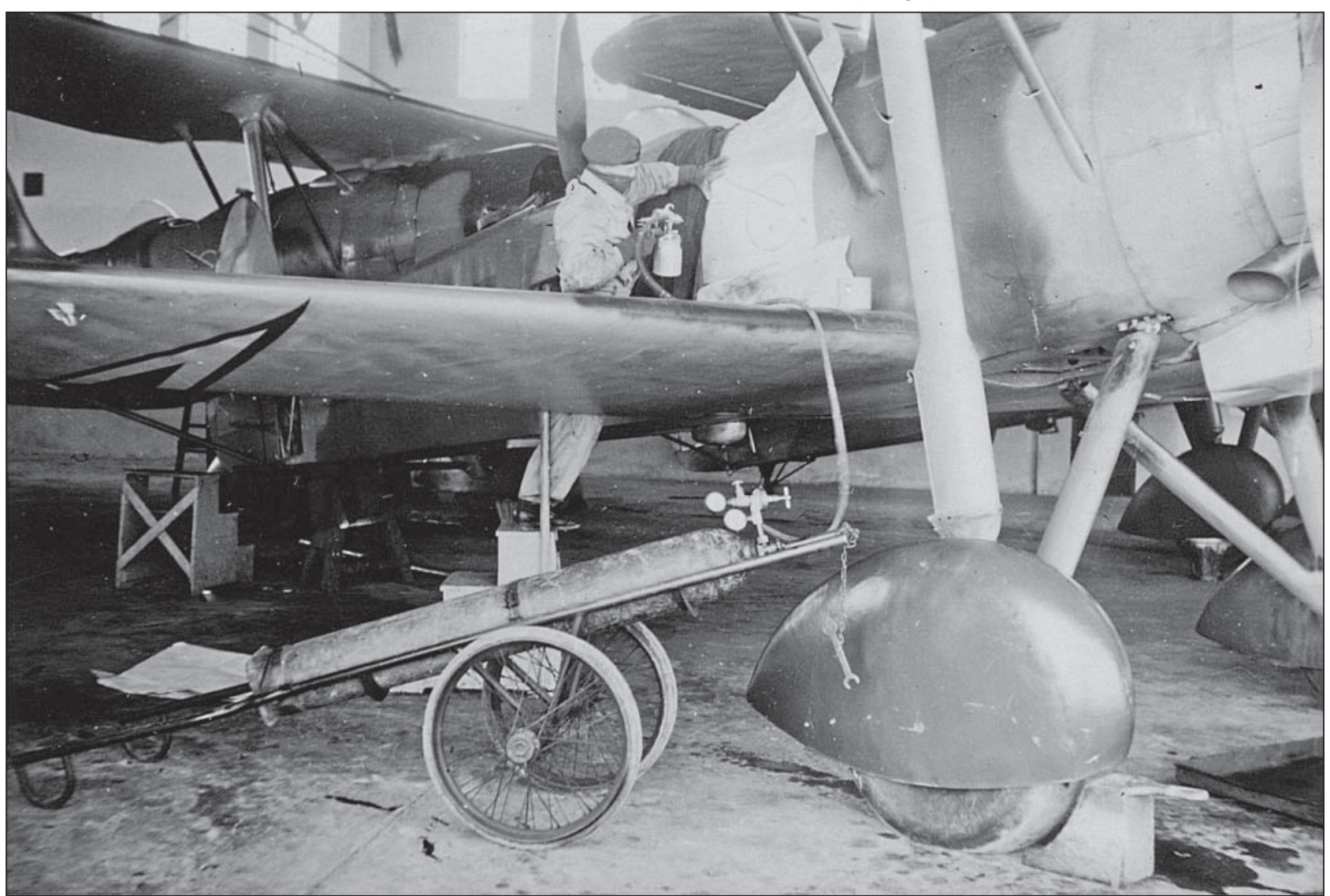




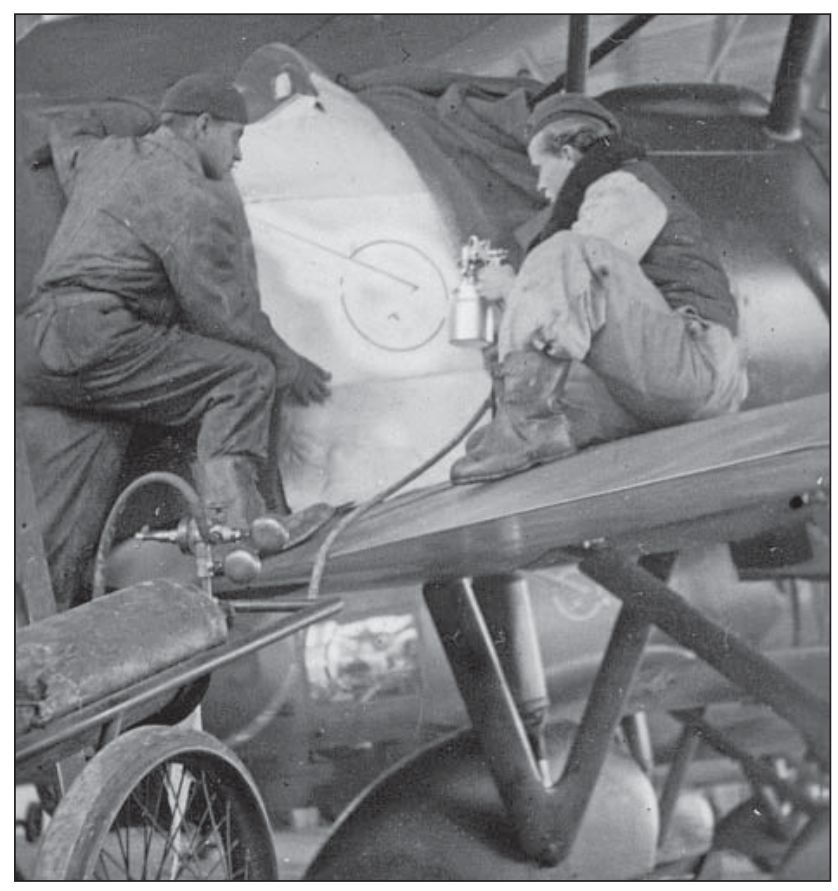

5. ábra. Készül a századjelvény: a festési munkálatok szórópisztolyos fázisa

7. ábra. A Magyar Szárnyak szerkesztője által írott levél 1940-böl

A HORTHY MIKLOS NEMZETI REPLLO ALAP TAMOGATÁSAVAL MEGJELENO

\section{NAAGYAIR SZARIRNYAE}

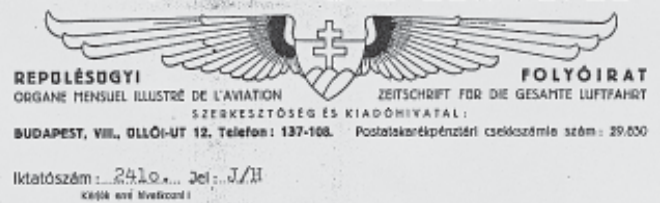

Naeysécos

dgoston Jozsef urnak,

Szombathe1y.

Repulotér III. ke. szd.

Polyó nó 14-én kelt nb. løvelát és küldeményét orönmel vettük. Hajzal kevés kivétellel alkalnasak a lapban valo leközlesre, 1Ey már december 1-i sxámunkban 1s efy vagy két rajz jön. Nem tuajuk, hoEy volna-e alka-

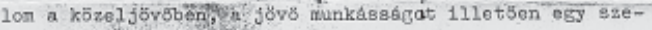
nélyes megbeszelésre, de ha erre alkalom volna, nuEg örünmel vennénk, ha szcrkesztösegünkben bennünket felkereshotne.

Rajzainak témél é feldolgozási módja maçözeliti elgondolásunkat s pagyon öriilnénk, ha nogboldorult icen kedves munkatérsunkat, Martinovice Béla flhadnsgy uri: lasaan-lassan munkảival potolnil tudná.

Fibgetlenili attol, hocy munkassagat körülményeinkhez képest honoráljuk, felnivjuk az1ves fieyelmát at anyagi eraekeken tul arra, horg a tárgyicör, nelybol téndit vâlaaztja legyen minden estoben a lehet8góg azcrint tanulsázos ès oktato háteriü, annál is inkább, rert munkúit loks:t3leg ninden számban szeretnök közöln1.

Abban a reményben, hogy a közeli iasben szendlyes regbeszélésínkre is sor kerül, vagejunk Eudapest, 1940. noverber 19-en

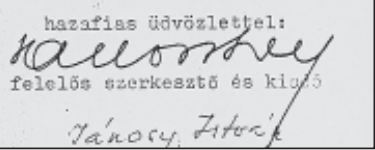

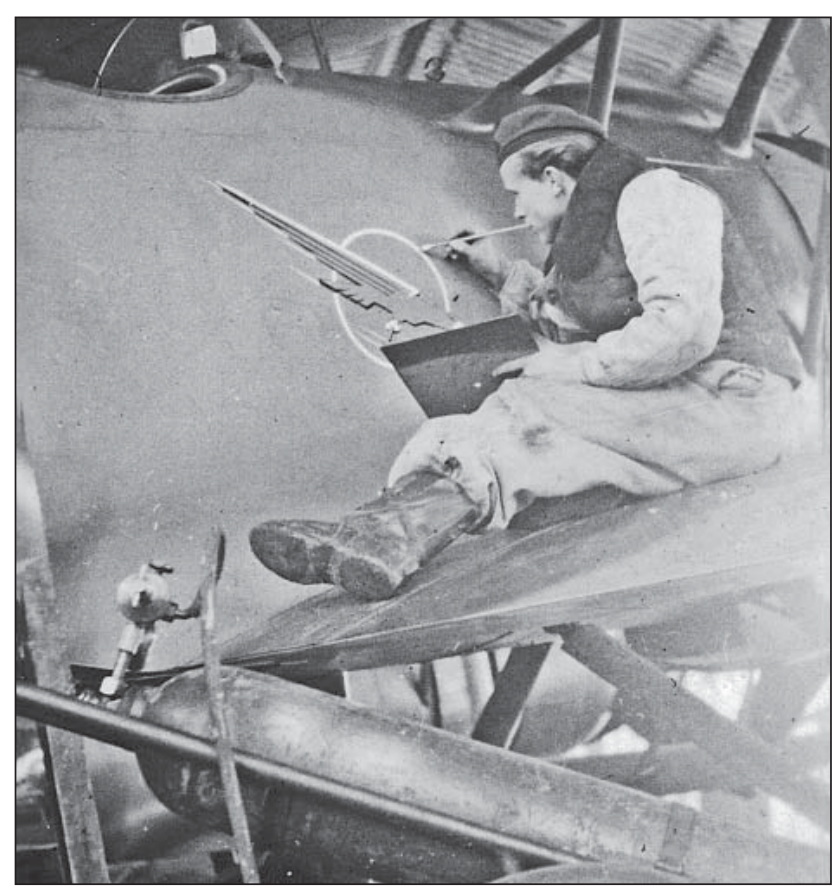

6. ábra. Készül a századjelvény: a festési munkálatok kézi kihúzásos fázisa, amit már ecsettel végeztek

Kis Ezüst Vitézségi Érmet és a német II. osztályú Vaskeresztet, valamint a Tüzkereszt I. fokozatát a koszorúval és kardokkal (ez utóbbit utólag, 1944-ben adományozták részére az 1941-es bevetéseiért). Emellett viselte mindhárom (Felvidéki, Erdélyi, Délvidéki) emlékérmet is. 1941. november 1-vel a Magyar Királyi Honvéd Légierő jelentős átszervezésen esett át, amelynek során a III. közelfelderítő század is feloszlatásra került. Ágoston József maradt Szombathelyen, ahol a REGVI oktatója lett. Itt készítette el 1942-ben a harmadik századjelvényét, a REGVI 1. századának. Ez volt az összefoglalásban már említett, korábban ismeretlen, publikálatlan századjelvény. Ez a tréfás jelvény egy gólyát ábrázolt, amely a nyakában átkötött szalagon egy pilótasapkás és -szemüveges, pólyában lévő pilótanövendéket szállít. Hogy a korábban a távolfelderítőknél más

8. ábra. A magyar királyi honvéd repülőgép-vezető iskolaosztály (REGVI) 1. századának jelvénye

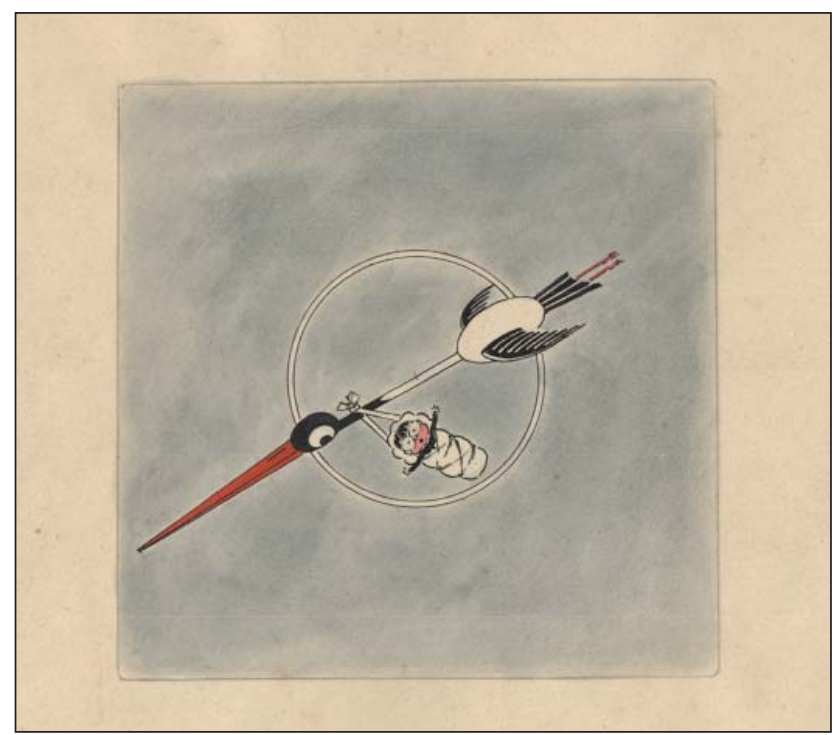




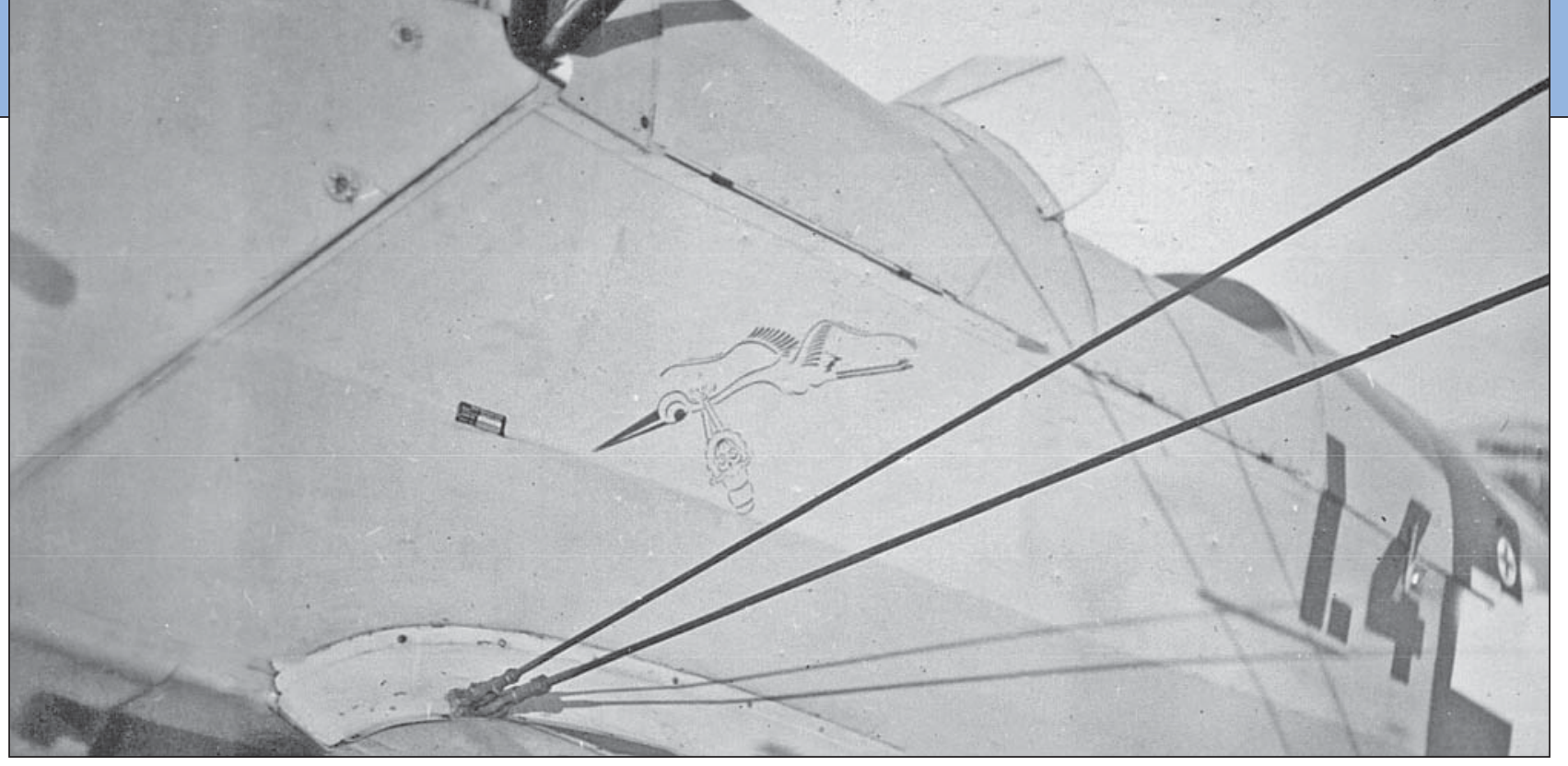

9. ábra. A Bücker 131 típusú oktató repülőgép a REGVI gólya jelvénnyel

formában már alkalmazott „Gólya” jelvény nem csak egy koncepció volt, arra a rajzon túl bizonyítékkent mellékelek egy fotót is, amelyen jól látható, hogy a REGVI legalább egy Bücker Jungmannjára fel is festették a pólyást szállító madáralakot (sablonnal).

A hosszú ideig a REGVI oktatójaként rendkívül eredményesen tevékenykedő Ágoston József 1942-ben, 1943-ban és 1944-ben is kapott egy-egy csapatparancsnoki okirati dicsérő elismerést a repülőgép-vezető kiképzés terén kifejtett kiváló és eredményes munkásságáért (itt különösen az Arado Ar 96-ossal végrehajtott mürepülő feladatok oktatása állt közel a szívéhez). Ágoston József 1944. május 1-én törzsőrmesterré lépett elő, majd a főtiszthelyettesi vizsga sikeres letétele után 1944. szeptember 20-án zászlóshelyettessé avatták. Ezt követően, 1944 november elején, a főtiszthelyettesi állománycsoport megszűnésével átminősítették hivatásos tiszti állományba, zászlósi rendfokozattal. Alakulatával, a REGVI-vel együtt az ősz és tél folyamán Vátról előbb Mesterházára, majd Bősárkányba települtek át. Ágoston Józsefet 1945. február 1-vel áthelyezték Tapolcára, a megalakuló 1/III. csatarepülő osztályhoz, tiszti repülőgép-vezetői beosztásba. Repülőgépekkel fel nem szerelt alakulatával 1945. március 27-ei indulással Zeltwegbe, majd onnan Pockingba vonult vissza, itt esett amerikai hadifogságba 1945. május 5-én. A hadifogságból 1945. december 27-én tért haza, ahol kezdetben esztergályosként dolgozott, majd 1948. szeptember 20-tól az Országos Magyar Repülő Egyesület (OMRE) alkalmazásában

\section{0. ábra. Ágoston József repülőigazolványa}

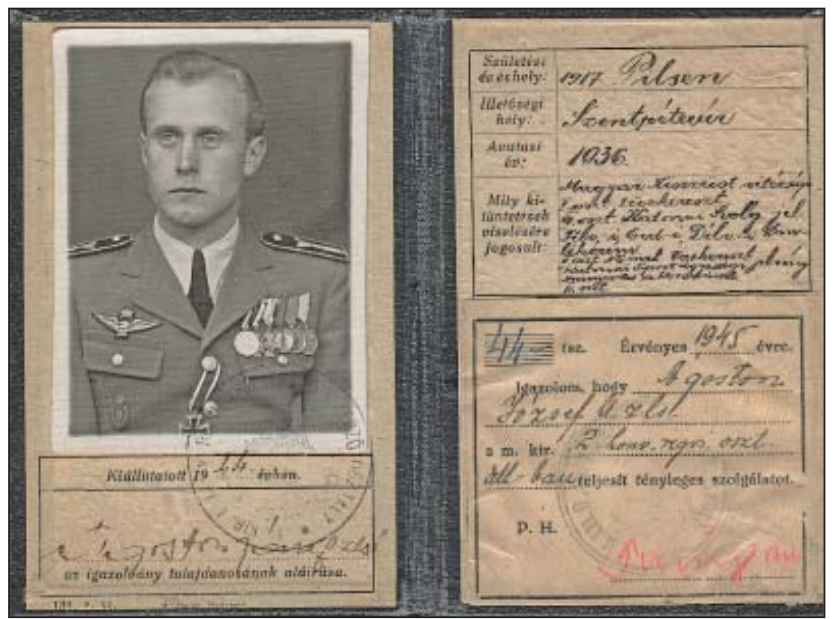

a Szeged melletti Algyő repterén előbb motoros oktató, majd az iskola és a reptér parancsnoka volt, innen azonban 1951 tavaszán háborús múltja, egykori hivatásos tiszti mivolta miatt mint megbízhatatlant eltávolították, többé nem repülhetett. Ezt követően műszaki vonalon helyezkedett el az Egyesült Izzónál (és itt is maradt 1988-as nyugdíjba meneteléig). Az 1956-os forradalom és szabadságharc leverése után meginduló nagyarányú felülvizsgálatok őt is elérték. Munkahelye - ahol akkor múszaki rajzolóként és gépszerkesztő technikusként, majd később gyártásfejlesztő technikusként dolgozott - hiába adott róla pozitív véleményt 1957 őszén („Négy-öt év óta ismerjük. Pártonkívüli volt és jelenleg is az. Munkáját becsületesen elvégzi. Dolgozótársai szeretik. Nem politizáló egyén. Politikai megnyilvánulásai nincsenek. Munkájának él...") és tette ugyanezt a háztömbmegbízott is (,rendes, komoly ember"), a háborúban a Szovjetunió feletti repülései, elnyert hadikitüntetései és egykori hivatásos tiszti mivolta miatt a Néphadsereg szervei végül 1958. március 25-én a HM 0273. sz. parancscsal lefokozták honvéddé.

A Magyar Veterán Repülők Egyesületének 1989-es megalakulásától aktív tagja volt. A rendszerváltoztatást követően, Ágoston József kérelmére a honvédelmi miniszter 1993. március 31-én 25/1993. számú parancsában visszaadta elvett rendfokozatát és egyben előléptette hadnagygyá. A veterán repülős 1998. december 7-én hunyt el Budapesten, kis unokája kísérése közben érte a végzetes szívroham. Ő úgy mondta volna: szolgálatteljesítés közben... Ágoston József az egykori Magyar Királyi Honvéd Légierő nagyon értékes tagja volt.

\section{JegYzetEK}

1 Dr. Csizek Zoltán: Magyar repülőszázadok és századjelvényeik 1933-1945. Pécs, Opus, 2006. 132 o.

2 Ágoston József életrajzának forrása a család által megőrzött dokumentumokon túl a HM HIM Központi Irattárában megtalálható 1197. sz. tiszti okmánygyűjtője.

3 Ágoston József Repülő leírása (előrész - másolata a szerző birtokában). Sajnos a Repülő leírás betétfüzetei elvesztek, megsemmisültek, így későbbi harci bevetései, oktatóként repült pontos óraszáma és összesített, a magyar királyi honvéd légierő keretein belül repült óraszáma részleteiben nem ismertek.

4 Ágoston József levele. In: Magyar Szárnyak Évkönyv 1991. 161. o.

5 Ágoston József Repülő leírása (előrész - másolata a szerző birtokában).

6 Ágoston József levele. In: Magyar Szárnyak Évkönyv 1991. 162. o. 